удк 338.48

DOI: https://doi.org/10.32851/2708-0366/2021.5.10

Скопень М.М.

кандидат економічних наук, доцент, викладач-методист, Київський державний коледж туризму та готельного господарства ORCID: https://orcid.org/ 0000-0003-0440-446X

Красавцева Л.Ю.

кандидат наук з державного управління, викладач-методист, Київський державний коледж туризму та готельного господарства ORCID: https://orcid.org/0000-0002-8187-7407

Skopen Mykola, Krasavtseva Liudmyla Kyiv State College of Tourism and Hospitality

\title{
ОПТИМІЗАЦІЯ РІВНЯ ДОХОДНОСТІ ГОТЕЛЮ НА ОСНОВІ ДИФЕРЕНЦІАЦІЇ ЦІН В УМОВАХ СЕЗОННОГО КОЛИВАННЯ ЗАВАНТАЖЕННЯ НОМЕРНОГО ФОНДУ
}

\author{
OPTIMIZATION OF THE LEVEL OF PROFITABILITY OF HOTEL \\ ON THE BASIS DIFFERENTIATION OF PRICES \\ IN CONDITIONS SEASONAL OSCILLATION LOADING NUMBER'S
}

У статті запропоновано технологію оптимізації рівня доходності готелю на основі диференціації вартості проживання в умовах сезонного коливання коефіиієнту завантаження номерного фонду. Технологія дає змогу управляти прибутковістю підприємства, збільиувати його ефективність функиіонування, щзо є актуальним у сучасних умовах готельного бізнесу. Для реалізації даної технології сформовано математичну модель, яка дає змогу порівняти річний дохід готелю за диференційованих ичін на послуги розміщення з річним доходом готелю від реалізації послуг гостинності за стабільної середньої циіні та стабільного середнього коефіиієнту завантаження номерного фонду. Окрім того, технологія оптимізації рівня доходності передбачає два варіанти ї̈ реалізації, а саме: попередню оиінку, тобто здійснення диференціації изін на основі завантаження готелю без урахування категорій номерів; уточнюючу оцінку, тобто здійснення диференціації цуін на основі завантаження окремих категорій номерів готелю. Вибір варіанту залежить від того, яка необхідна точність розрахунків. Представлену технологію можна рекомендувати для використання в навчальному процесі, а також для практичної діяльності підприємств готельного бізнесу.

Ключові слова: рівень доходності, доходність готелю, диферениіація вартості проживання, оптимізація изін.

В статье предложена технология оптимизации уровня доходности гостиницьь на основе дифференциации стоимости проживания в условиях сезонного колебания коэффициента загрузки номерного фонда. Технология позволяет управлять доходностью предприятия, увеличивать его эффективность функционирования, что является актуальным в современных условиях гостиничного бизнеса. Для реализации данной технологии сформирована математическая модель, которая позволяет сравнить годовой доход гостиницы при дифференциированных изенах на услуги размещеения с годовым доходом отеля от реализации услуг гостеприимства при стабильной средней иене и стабильном среднем коэффициенте загрузки номерного фонда. Кроме того, технология оптимизации уровня доходности предусматривает два варианта реализации, а именно: предварительную оценку, то есть осуществление дифференцииации ичен на основе загрузки отеля без учета категорий номеров; уточняюшую оценку, то есть осуществление дифференциации ичен на основе загрузки отдельных категорий номеров отеля. Выбор варианта зависит от того, какая необходима точность расчетов. Представленную технологию можно рекомендовать для использования в учебном прочессе, а также для практической деятельности предприятий гостиничного бизнеса.

Ключевые слова: уровень доходности, доходность отеля, дифференцииачия стоимости проживания, оптимизациия цеен. 
The article proposes the technology of optimizing the level of profitability of the hotel on the basis of differentiation of the cost of living in conditions of seasonal fluctuations in the load factor of the number of rooms. Technology allows you to manage the profitability of the enterprise, make the right decisions in shaping the level of profitability of the hotel, increase its efficiency, which is relevant in today's hotel business. To implement this technology, a mathematical model is formed, which allows to compare the annual income of the hotel at differentiated prices for accommodation services with the annual income of the hotel from the sale of hospitality services at a stable average price and stable average load factor. The calculations of the level of profitability according to this model show that the formation of prices based on their differentiation increases the income of the hotel business. Otherwise, the measure of price differentiation in the conditions of seasonal fluctuations of the load factor is not attractive. In addition, the technology of optimizing the level of profitability provides for two options for its implementation, namely: preliminary assessment, that is the implementation of price differentiation based on hotel occupancy without taking into account room categories; clarifying assessment, that is the implementation of price differentiation based on the loading of certain categories of hotel rooms. The choice of option depends on the required accuracy of calculations. In turn, the accuracy of the calculations is significantly affected by a clear differentiation of the load factor between the categories of numbers. For example, generalizing the load factor between room categories reduces the accuracy of calculations and, conversely, a detailed description of load factors by room category increases the accuracy of calculating the level of profitability. This approach to managing the profitability of the enterprise takes into account the demand and leads to an increase in the number of customers served, which allows you to maximize revenue from hospitality services and make a reasonable profit. The presented technology can be recommended for use in the educational process, as well as for the practical activities of the hotel business.

Key words: level of profitability, profitability of hotel, differentiation of cost of living, optimization of prices.

Постановка проблеми. Вивчення формування вартості проживання в готелях, яка визначає їх доходність, свідчить про те, що в даному процесі враховуються такі основні чинники, як витрати та цільовий прибуток, ціноутворення конкурентів і попит на послуги розміщення. При цьому практично не застосовується технологія диференціації цін на основі сезонного коливання коефіцієнту завантаження номерного фонду.

Аналіз останніх досліджень і публікацій. У багатьох літературних джерелах, які присвячені маркетинговим дослідженням, достатньо добре розглянуто загальні принципи ціноутворення, у тому числі й у готельному бізнесі [1; 2; 4 та ін.]. Окрім того, запропоновано методику оптимізації вартості путівок для підприємств санаторно-курортної сфери [3], а також технологію оптимізації вартості турпакетів та екскурсійних турів [5]. Однак жодне видання не дає чіткої відповіді, як можна провести оптимізацію рівня доходності готелю на основі диференціації вартості проживання в умовах сезонного коливання коефіцієнту завантаження номерного фонду.

Формулювання цілей статті. Мета статті - запропонувати технологію оптимізації рівня доходності готелю на основі диференціації вартості проживання в умовах сезонного коливання коефіцієнту завантаження номерного фонду.

Виклад основного матеріалу. У сучасних умовах, коли швидкими темпами розвивається сфера гостинності, виникає нагальна потреба оперативно управляти бізнес-процесами та приймати правильні рішення в різних аспектах, у тому числі під час формування рівня доходності готелю. Розглянемо запропоновану технологію на умовному прикладі готелю, який має 332 комфортабельних номери різних категорій та 564 місця проживання. Його розвиток зумовлює пошук прийнятної вартості проживання у номерному фонді, яка б забезпечувала зростання кількості обслугованих клієнтів, ураховувала попит і водночас давала б можливість максимізувати дохід від реалізації послуг та отримання бажаного прибутку. У цьому разі модель оптимізації рівня доходності готелю ( $\left.P_{\text {д }}\right)$ має такий вигляд:

$$
P_{\partial}=\frac{Д_{\partial u}}{Д_{c y}}>1 \rightarrow \max ,
$$


де $Д_{\partial и}-$ річний дохід готелю за диференційованих цін на послуги розміщення;

$Д_{c u}$ - річний дохід готелю від реалізації послуг гостинності за стабільної середньої ціни та стабільного середнього коефіцієнту завантаження номерного фонду.

Слід зауважити, що оптимізацію рівня доходності готелю можна реалізувати за двома варіантами:

1. Попередньою оцінкою, тобто здійснення диференціації цін на основі завантаження готелю без урахування категорій номерів.

2. Уточнюючою оцінкою, тобто здійснення диференціації цін на основі завантаження окремих категорій номерів готелю.

Технологія попередньої оцінки рівня доходності готелю. Припустимо, що на основі щомісячного завантаження номерного фонду (рис. 1) середній коефіцієнт у звітному році становив 43\%, а середня ціна - 1804 грн/добу (табл. 1).

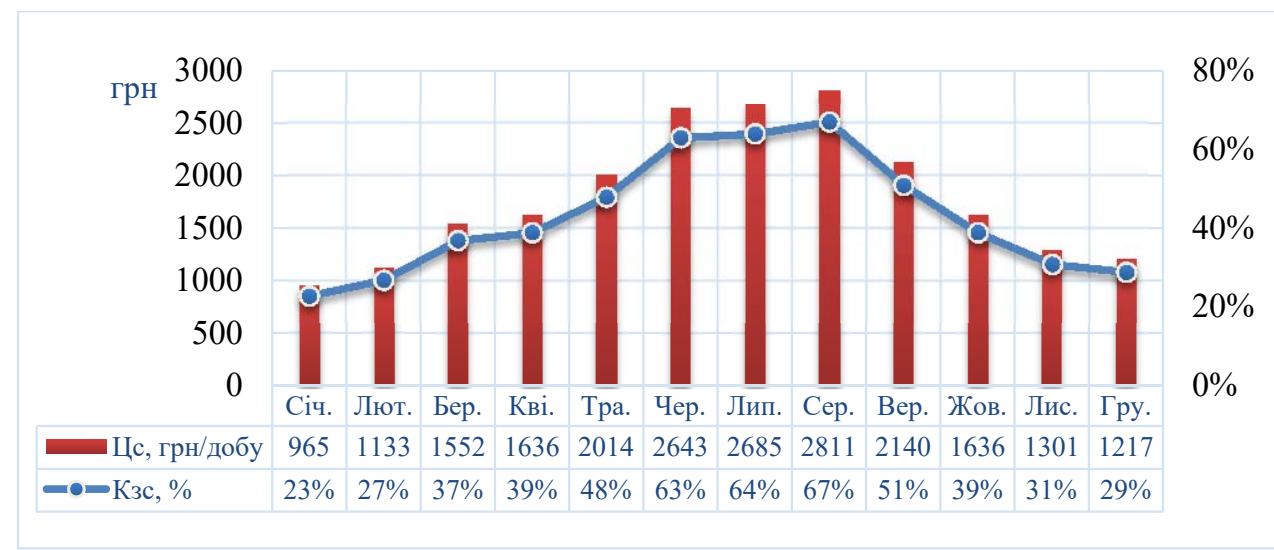

Рис. 1. Середня циіна (Цс) стійки та коефіиієнт завантаження (Кзс) номерного фонду

Джерело: розроблено авторами

Ураховуючи, що рік має 365 днів, можна розрахувати річний дохід від реалізації готельних послуг ( $Д_{c y}$ ) за стабільної середньої ціні та стабільного середнього коефіцієнту завантаження за формулою:

$$
Д_{c y}=365 * K_{M} * L_{c} * K_{3 c},
$$

де $K_{м}$ - загальна кількість місць проживання;

$\bigsqcup_{c}-$ середня вартість проживання, грн/добу;

$K_{\text {зс }}-$ середній коефіцієнт завантаження номерного фонду.

Тоді в нашому випадку:

$$
Д_{c u}=365 * 564 * 1804 * 0,43 / 1000=159690 \text { тис грн . }
$$

Тепер проведемо розрахунок диференційованих цін без урахування категорій номерів. Диференційована вартість проживання по кожному і-му місяцю (Ці) обчислюється за формулою:

$$
Ц_{i}=\frac{K_{3 i}}{K_{3 c}} * Ц_{c},
$$

де $K_{з і}$ - коефіцієнт завантаження і-го місяця.

Наприклад, для січня диференційована ціна становитиме:

$$
L_{\text {січ. }}=\frac{0,23}{0,43} * 1804=965 \text { грн . }
$$

Аналогічні розрахунки здійснюються і по інших місяцях року (табл. 2). 
Визначення середньозваженої вартості проживання

\begin{tabular}{|c|c|c|c|}
\hline Категорія номерів & $\begin{array}{l}\text { Кількість } \\
\text { номерів }\end{array}$ & $\begin{array}{l}\text { Середня ціна, } \\
\text { грн/добу }\end{array}$ & Всього, грн/добу \\
\hline Економ або стандарт одномісний & 184 & 1100 & 202400 \\
\hline Економ або стандарт двомісний & 246 & 1610 & 396060 \\
\hline $\begin{array}{l}\text { Стандарт покращений } \\
\text { або напівлюкс }\end{array}$ & 98 & 2653 & 259994 \\
\hline Люкс & 36 & 4420 & 159120 \\
\hline Разом & 564 & - & 1017574 \\
\hline \multicolumn{2}{|c|}{ Середньозважена ціна: } & 1804 & \\
\hline
\end{tabular}

Джерело: розроблено авторами

Місячний дохід $\left(\mathrm{V}_{\mathrm{i}}\right.$ ) за диференційованої ціни обчислюється за формулою:

$$
\mathrm{V}_{\mathrm{i}}=\mathrm{K}_{д і} * \mathrm{~K}_{M} * K_{3 i} * Ц_{i},
$$

де $K_{\partial i}$ - кількість днів в і-му місяці.

Наприклад, для січня місячний дохід за диференційованої ціни становитиме:

$$
\mathrm{V}_{\text {січ. }}=\frac{31 * 564 * 0,23 * 965}{1000}=3880 \text { тис грн. }
$$

Таблиця 2

Розрахунок диференційованих цін та доходу готелю

\begin{tabular}{|l|c|c|c|}
\hline \multicolumn{1}{|c|}{ Місяць } & $\begin{array}{c}\text { Коефіціснт } \\
\text { завантаження }\end{array}$ & $\begin{array}{c}\text { Диференційована } \\
\text { ціна, грн }\end{array}$ & $\begin{array}{c}\text { Місячний дохід, } \\
\text { тис грн }\end{array}$ \\
\hline Січень & 0,23 & 965 & 3880 \\
\hline Лютий & 0,27 & 1133 & 4830 \\
\hline Березень & 0,37 & 1552 & 10042 \\
\hline Квітень & 0,39 & 1636 & 10797 \\
\hline Травень & 0,48 & 2014 & 16900 \\
\hline Червень & 0,63 & 2643 & 28174 \\
\hline Липень & 0,64 & 2685 & 30045 \\
\hline Серпень & 0,67 & 2811 & 32927 \\
\hline Вересень & 0,51 & 2140 & 18463 \\
\hline Жовтень & 0,39 & 1636 & 11157 \\
\hline Листопад & 0,31 & 1301 & 6822 \\
\hline Грудень & 0,29 & 1217 & 6169 \\
\hline & & $Д_{\partial u}$, mис. $2 p н$ & 180206 \\
\hline
\end{tabular}

Джерело: розроблено авторами

Аналогічні розрахунки здійснюються і по інших місяцях року (табл. 2), що дає можливість зробити підсумок річного доходу за диференційованих цін, тобто $Д_{\partial и}=180206$ тис грн. Тепер, знаючи річний дохід від реалізації готельних послуг за стабільної середньої ціни та стабільного середнього коефіцієнту завантаження (159690 тис грн), а також річний дохід за диференційованих цін (180 206 тис грн), можна обчислити за формулою (1) рівень доходності готелю: 


$$
P_{\partial}=\frac{180206}{159690}=1,128 .
$$

Отже, обчислений рівень доходності готелю свідчить про те, що формування цін на основі їх диференціації збільшує дохід готелю на 12,8\%, а даний захід є ефективним.

Слід зауважити, що в наведеному прикладі диференціації цін взято за основу середню ціну готелю, а не ціни за категорією номерів. Це вплинуло на точність розрахунку рівня доходності готелю.

Технологія уточнюючої оцінки рівня доходності готелю. Спочатку обчислюються диференційовані ціни за категоріями номерів по кожному місяцю. Наприклад, для номерів економ або стандарт одномісний у січні диференційована ціна за формулою (3) становитиме (табл. 3):

$$
\bigsqcup_{\text {січ. }}=\frac{0,23}{0,43} * 1100=588 \text { грн } / \text { добу. }
$$

Аналогічні розрахунки здійснюються за іншими категоріями номерного фонду та місяцями року.

Тепер обчислюється річний дохід від реалізації готельних послуг за стабільної середньої ціни та стабільного середнього коефіцієнту завантаження ( $\left.Д_{c y}^{\kappa}\right)$ за категоріями номерів. Наприклад, для номерів економ або стандарт одномісний дохід за формулою (2) становитиме (табл. 3):

$$
Д_{c u}^{\kappa}=\frac{365 * 0,43 * 1100 * 184}{1000}=31767 \text { тис грн. }
$$

Аналогічні розрахунки здійснюються за іншими категоріями номерів.

Тоді, річний дохід за стабільної середньої ціни та стабільного середнього коефіцієнту завантаження за усіма категоріями номерів ( $Д_{c y}^{\kappa}$ ) становитиме (табл. 3 ):

$$
\left(Д_{c u}^{\kappa}\right)=31767+62162+40806+24974=159708 \text { тис грн } .
$$

Далі розраховуються доходи за категоріями номерів по кожному місяцю. Наприклад, для номерів економ або стандарт одномісний в січні дохід за диференційованої ціни за формулою (4) становитиме (табл. 4):

$$
\mathrm{V}_{\text {січ. }}=(31 * 0,23 * 588 * 184) / 1000=772 \text { тис грн . }
$$

\begin{tabular}{|c|c|c|c|c|c|}
\hline \multirow[b]{2}{*}{ Місяць } & \multirow{2}{*}{$\begin{array}{c}\text { Місячний } \\
\text { середній } \\
\text { коефіціснт } \\
\text { завантаження }\end{array}$} & \multicolumn{4}{|c|}{ Диференційовані ціни, грн/добу } \\
\hline & & $\begin{array}{c}\text { Економ або } \\
\text { стандарт } \\
\text { одномісний }\end{array}$ & $\begin{array}{c}\text { Економ або } \\
\text { стандарт } \\
\text { двомісний }\end{array}$ & $\begin{array}{c}\text { Стандарт } \\
\text { покращений } \\
\text { або напівлюкс }\end{array}$ & Люкс \\
\hline 1 & 2 & 3 & 4 & 5 & 6 \\
\hline Січень & 0,23 & 588 & 861 & 1419 & 2364 \\
\hline Лютий & 0,27 & 691 & 1011 & 1666 & 2775 \\
\hline Березень & 0,37 & 947 & 1385 & 2283 & 3803 \\
\hline Квітень & 0,39 & 998 & 1460 & 2406 & 4009 \\
\hline Травень & 0,48 & 1228 & 1797 & 2961 & 4934 \\
\hline Червень & 0,63 & 1612 & 2359 & 3887 & 6476 \\
\hline Липень & 0,64 & 1637 & 2396 & 3949 & 6579 \\
\hline Серпень & 0,67 & 1714 & 2509 & 4134 & 6887 \\
\hline Вересень & 0,51 & 1305 & 1910 & 3147 & 5242 \\
\hline Жовтень & 0,39 & 998 & 1460 & 2406 & 4009 \\
\hline
\end{tabular}

Таблиця 3

Диференційовані ціни за категоріями номерів, грн/добу, та результати обчислення $Д_{c u}^{\kappa}$ 
Продовження Таблиці 3

\begin{tabular}{|l|c|c|c|c|c|}
\hline \multicolumn{1}{|c|}{1} & 2 & 3 & 4 & 5 & 6 \\
\hline Листопад & 0,31 & 793 & 1161 & 1913 & 3187 \\
\hline Грудень & 0,29 & 742 & 1086 & 1789 & 2981 \\
\hline Річний $K_{\text {зс }}$ & \multicolumn{5}{|c|}{0,43} \\
\hline Середня ціна, грн/добу & 1100 & 1610 & 2653 & 4420 \\
\hline Кількість місць & 184 & 246 & 98 & 36 \\
\hline $\begin{array}{l}Д_{\text {си }}^{\kappa} \text { разом, } \\
\text { в тому } \\
\text { числі за } \\
\begin{array}{l}\text { категоріями } \\
\text { номерів, тис } \\
\text { грн }\end{array}\end{array}$ & 31767 & 62162 & 40806 & 24974 \\
\hline
\end{tabular}

Джерело: розроблено авторами

Аналогічні розрахунки здійснюються за іншими категоріями номерного фонду та місяцями року.

Обчислюється річний дохід по кожному місяцю за всіма категоріями номерного фонду. Наприклад, за січень річний дохід ( $Д_{\text {січ. }}$ ) становитиме (табл. 4):

Таблиця 4

Доходи за категоріями номерів та результати обчислення ( $\left.Д_{\partial u}\right)$

\begin{tabular}{|c|c|c|c|c|c|}
\hline \multirow[b]{2}{*}{ Місяць } & \multicolumn{4}{|c|}{ Місячний дохід, тис грн } & \multirow[b]{2}{*}{$\begin{array}{l}\text { Річний дохід } \\
\left(Д_{\partial u}\right), \text { тис. грн }\end{array}$} \\
\hline & $\begin{array}{c}\text { Економ або } \\
\text { стандарт } \\
\text { одномісний }\end{array}$ & $\begin{array}{c}\text { Економ або } \\
\text { стандарт } \\
\text { двомісний }\end{array}$ & $\begin{array}{c}\text { Стандарт } \\
\text { покращений } \\
\text { або напівлюкс }\end{array}$ & Люкс & \\
\hline Січень & 772 & 1510 & 992 & 607 & 3881 \\
\hline Лютий & 995 & 1947 & 1278 & 782 & 5003 \\
\hline Березень & 1998 & 3909 & 2566 & 1570 & 10043 \\
\hline Квітень & 2148 & 4203 & 2759 & 1689 & 10798 \\
\hline Травень & 3362 & 6579 & 4319 & 2643 & 16902 \\
\hline Червень & 5605 & 10967 & 7199 & 4406 & 28177 \\
\hline Липень & 5977 & 11695 & 7677 & 4699 & 30048 \\
\hline Серпень & 6550 & 12818 & 8414 & 5150 & 32931 \\
\hline Вересень & 3673 & 7187 & 4718 & 2887 & 18465 \\
\hline Жовтень & 2219 & 4343 & 2851 & 1745 & 11158 \\
\hline Листопад & 1357 & 2655 & 1743 & 1067 & 6822 \\
\hline Грудень & 1227 & 2401 & 1576 & 965 & 6170 \\
\hline Разом & 35882 & 70215 & 46093 & 28209 & 180399 \\
\hline
\end{tabular}

Джерело: розроблено авторами

$$
Д_{\text {січ. }}=772+1510+992+607=3881 \text { тис грн . }
$$

Аналогічні розрахунки здійснюються за іншими місяцям року. Тоді річний дохід за диференційованих цін ( $Д_{\partial и}$ ) становитиме суму доходів за 12 місяців, тобто (табл. 4):

$$
Д_{\partial и}=35882+70215+46093+28209=180399 \text { тис грн. }
$$


Тепер, знаючи річний дохід від реалізації готельних послуг за стабільної середньої ціни (159 708 тис грн), а також річний дохід за диференційованих цін (180 399 тис грн), можна обчислити рівень доходності готелю:

$$
P_{\partial}=\frac{180399}{159708}=1,13 .
$$

Отже, обчислений більш точно рівень доходності $(1,13)$ свідчить про те, що формування цін на основі їх диференціації з урахування категорій номерного фонду збільшує прибутковість готелю вже на 13\% порівнянні з обчисленим рівнем доходності готелю без урахування категорій номерів $(12,8 \%)$. Тут також слід зауважити, що на збільшення точності обчислення рівня доходності суттєво впливає чітка диференціація коефіцієнту завантаження між категоріями номерів.

Висновки. Для оптимізації рівня доходності будь-який готель може здійснювати диференціацію цін залежно від сезонного попиту на послуги гостинності у цілому по готельному підприємству без урахування категорій номерів. Однак в окремих випадках, коли необхідна більша точність розрахунків, доцільно проводити диференціацію цін з урахуванням визначених категорій номерів. За таких умов готель повинен надавати кімнати за низькою ціною для приїжджих впродовж періоду низької наповненості та резервувати кімнати впродовж пікового попиту для бізнесменів, які мають можливість сплатити номери за повними розцінками. При цьому готель здебільшого виграє, оскільки управління доходами спрямоване на максимізацію доходу, а не на скорочення витрат.

Безумовно, наведена вище технологія оптимізації рівня доходності дає змогу підвищити якість вивчення економіки готельного бізнесу. Ї̈̈ можна рекомендувати для використання в практичній діяльності підприємств готельної сфери, а також у навчальному процесі.

\section{Список використаних джерел:}

1. Агафонова Л.Г., Агафонова О.С. Туризм, готельний та ресторанний бізнес: ціноутворення, конкуренція, державне регулювання : навчальний посібник. Київ : Знання України, 2002. $358 \mathrm{c}$.

2. Мальська М.П., Мандюк Н.Л. Основи маркетингу у туризмі : підручник. Київ : Центр учбової літератури, 2016. $336 \mathrm{c.}$

3. Миронов Ю.Б., Новицька-Колодіна А.О. Методика оптимізації цінової політики підприємств рекреаційного туризму. Молодь і ринок. 2005. № 1(11). С. 106-109.

4. Роглєв Х.Й. Основи готельного менеджменту : навчальний посібник. Київ : КОНДОР, 2005. $408 \mathrm{c}$.

5. Скопень М.М., Сукач М.К. Інформаційні системи і технології маркетингу в туризмі : навчальний посібник. Київ : Каравела, 2010. 336 с.

\section{References:}

1. Ahafonova L.H., Ahafonova O. YE. (2002) Turyzm, hotelnyi ta restorannyi biznes: tsinoutvorennia, konkurentsiia, derzhavne rehuliuvannia [Tourism, hotel and restaurant business: pricing, competition, government regulation]. Kyiv: Znannia Ukrainy. (in Ukrainian)

2. Malska M. P., Mandiuk N. L. (2016) Osnovy marketynhu u turyzmi [Fundamentals of marketing in tourism]. Kyiv: Tsentr uchbovoi literatury. (in Ukrainian)

3. Myronov Yu.B., Novytska-Kolodina A.O. (2005) Metodyka optymizatsii tsinovoi polityky pidpryiemstv rekreatsiinoho turyzmu [Methods of optimizing the pricing policy of recreational tourism enterprises]. Molod i rynok, no. 1 (11), pp. 106-109.

4. Rohliev Kh.I. (2005) Osnovy hotelnoho menedzhmentu [Fundamentals of hotel management]. Kyiv: KONDOR. (in Ukrainian)

5. Skopen M.M., Sukach M.K. (2010) Informatsiini systemy i tekhnolohii marketynhu v turyzmi [Information systems and marketing technologies in tourism]. Kyiv: KARAVELA. (in Ukrainian) 